\title{
Evaluation of Different Digestible Lysine Levels for Male Broilers During the Period of 18 to 40 Days of Age
}

\section{mAuthor(s)}

Carlos TCF

Marino $\mathrm{CT}^{\top}$

Silva NVP da

Barbosa LCGS'

Reis RN"

Muramatsu K"

Araújo CS da S

Araújo LF'

Department of Animal Science, University of Sao Paulo, Pirassununga, SP, Brazil.

" BR Foods. Videira, SC, Brazil.

\section{Mail Adress}

Corresponding author e-mail address Teresa Cristina de Freitas Carlos.

Department of Animal Science, University of Sao Paulo, Pirassununga, SP, Brazil. E-mail: teresa_cristina_c@hotmail.com

\section{nKeywords}

Amino acids, poultry production, performance, ideal protein, parts yield.

\section{ABSTRACT}

A total of 1.500 male Cobb 500 broilers were used to determine the optimal digestible lysine level for 18 to 40-day-old broilers. The experimental period started when broilers were 18 days old and had an initial average weight of $737 \pm 20 \mathrm{~g}$. A completely randomized experimental design was applied, with five lysine levels, totaling five treatments with 10 replicates of 30 birds each. The experimental diets contained equal energy and protein levels, and 0.86, 0.95, 1.04, 1.13, and $1.22 \%$ digestible lysine. The following parameters were evaluated: average body weight at 40 days of age, daily weight gain, daily feed intake, feed conversion ratio, carcass yield and parts yield, and abdominal fat percentage. There was a quadratic effect $(p<0.05)$ of digestible lysine levels on average body weight at 40 days of age, daily weight gain, and breast yield, and a cubic effect on feed conversion ratio and abdominal fat. There was no influence of lysine levels of daily feed intake, carcass yield, leg, or wing yields. It was concluded that digestible lysine requirements for male broilers during the evaluated period was $1.22 \%$ for performance and $1.04 \%$ for carcass yield.

\section{INTRODUCTION}

Genetic improvement is constantly applied in modern poultry production, and therefore broiler nutritional requirements need to be regularly updated in order to allow them to express their full genetic potential. In particular, protein inclusion in feed formulation has greatly developed during the last few years. Previously based on crude protein and total amino acids, feed formulation now applies the concept of ideal protein and digestible amino acids.

The application of the ideal protein concept allows reducing crude protein because diets contain a precise balance of essential amino acids formulated to supply the birds' nutritional requirements for maintenance and protein accretion. Moreover, the energy that is required to excrete excessive nitrogen is spared. Therefore, there is a reduction in production costs, better performance, and less environmental pollution due to lower nitrogen excretion.

Lysine is the second limiting amino acid in broiler diets. It is used as reference in the concept of ideal protein because it is strictly essential, i.e., it does not have any endogenous synthesis route. Also, there are several studies on its digestibility in many feedstuffs and on its requirements at all production phases, and the laboratory analysis to determine its content in feedstuffs, feeds, and animal tissues is accurate, and relatively simple. Moreover, its supplementation to diets is not expensive.

Several factors may affect lysine requirements, such as genetic strain, age, sex, thermal environment, stress, dietary protein and metabolizable 
energy contents, and especially the feedstuffs included in feed formulation (Conhalato, 1998).

The objective of the present study was to determine the optimal digestible lysine levels for male broilers during the period of 18 to 40 days of age.

\section{MATERIALS AND METHODS}

The experiment was carried out in the experimental poultry house of a broiler company located in the state of Santa Catarina, Brazil. A total of 1,500 male Cobb 500 broilers, weighing $45.3 \pm 2.5 \mathrm{~g}$ at housing, were used. A completely randomized experimental design was applied, with five lysine levels, totaling five treatments with 10 replicates of 30 birds each, distributed in $5.5-\mathrm{m}^{2}$ pens.

The sides of the experimental house were equipped with mesh and curtains, and the concrete floor was covered with reused wood-shavings litter. Feed and water were supplied ad libitum in tube feeders and nipple drinkers. Natural lighting was adopted. Gas brooders were used. Until 17 days of age, all birds were submitted to the feeding program and fed the nutritional levels recommended by the genetic company's manual.

The experiment started when broilers were 18 days old. Birds which body weight was $\pm 10 \%$ of flock average body weight were selected for the experiment (initial weight: $737 \pm 20 \mathrm{~g}$ ).

Diets were supplied as mash, and were based on corn and soybean meal, and supplemented with methionine, threonine, tryptophan, valine, isoleucine, and arginine. Diets contained equal energy and protein levels, and were formulated based on the ideal protein concept in order to prevent any amino acid limitation, except for lysine. The ingredient composition of the experimental diets is shown in Table 1.

Table 1 - Ingredient composition of the experimental diets.

\begin{tabular}{lcc}
\hline Ingredients & Treatment 1 & Treatment 5 \\
\hline Corn & 623.350 & 624.550 \\
\hline Soybean meal 46\% & 295.100 & 298.000 \\
\hline Soybean soapstock & 31.800 & 31.900 \\
\hline Phosphate 18\% & 13.000 & 13.000 \\
\hline Calcitic limestone & 9.000 & 9.000 \\
\hline L-glutamic acid & 9.000 & \\
\hline DL-methionine & 4.100 & 4.050 \\
\hline Ground salt & 4.000 & 3.200 \\
\hline L-threonine 98.5\% & 2.000 & 1.950 \\
\hline Mineral premix & 2.000 & 2.000 \\
\hline L-valine & 1.400 & 1.400 \\
\hline L-arginine 98.5\% & 1.400 & 1.400 \\
\hline L-isoleucine 98.5\% & 1.250 & 1.200 \\
\hline Vitamin premix & 1.000 & 1.000 \\
\hline Sodium bicarbonate + & 0.800 & 2.250 \\
potassium carbonate & & \\
\hline Choline chloride 60\% & 0.500 & 0.500 \\
\hline L-tryptophan 98\% & 0.300 & 0.300 \\
\hline L-lysine 78.8\% & & 4.300 \\
\hline Total & 1000.000 & 1000.000 \\
\hline
\end{tabular}

L-lysine (78.8\%) was supplemented at the expense of L-glutamic acid, and the experimental diets therefore contained $0.86,0.95,1.04,1.13$, and $1.22 \%$ digestible lysine.

Two basal diets were manufactured: Treatment 1 (T1), containing $0.86 \%$ lysine and Treatment 5 (T5), containing $1.22 \%$ lysine, which were mixed to obtain the remaining treatments: Treatment $2-5 \% \mathrm{~T} 1+$ 25\% T5, Treatment $3-50 \%$ T1 + 50\% T5, Treatment $4-25 \% \mathrm{~T} 1+75 \% \mathrm{~T} 5$. The nutritional content of the experimental diets are described in Table 2.

Birds, feed supply and feed residues were weekly weighed. Based on these measurements, the following

Table 2 - Nutritional levels of the experimental diets.

\begin{tabular}{|c|c|c|c|c|c|}
\hline Nutritional levels & $\mathrm{T} 1$ & $\mathrm{~T} 2$ & T3 & $\mathrm{T} 4$ & T5 \\
\hline Crude protein (\%) & 20.00 & 20.00 & 20.00 & 20.00 & 20.00 \\
\hline Metabolizable energy (kcal/kg) & 3200 & 3200 & 3200 & 3200 & 3200 \\
\hline Calcium (\%) & 0.950 & 0.950 & 0.950 & 0.950 & 0.950 \\
\hline Available phosphorus (\%) & 0.440 & 0.440 & 0.440 & 0.440 & 0.440 \\
\hline Sodium (\%) & 0.190 & 0.190 & 0.190 & 0.190 & 0.190 \\
\hline Choline (ppm) & 1400 & 1400 & 1400 & 1400 & 1400 \\
\hline Digestible lysine (\%) & 100 & 100 & 100 & 100 & 100 \\
\hline Digestible methionine (\%) & 76 & 69 & 63 & 58 & 54 \\
\hline Digestible methionine + cystine (\%) & 108 & 98 & 89 & 82 & 76 \\
\hline Digestible threonine (\%) & 93 & 84 & 77 & 71 & 66 \\
\hline Digestible tryptophan (\%) & 26 & 23 & 21 & 19 & 18 \\
\hline Digestible arginine (\%) & 148 & 134 & 123 & 113 & 105 \\
\hline Digestible valine (\%) & 107 & 97 & 88 & 81 & 75 \\
\hline Digestible isoleucine (\%) & 99 & 89 & 82 & 75 & 70 \\
\hline
\end{tabular}


parameters were evaluated: average body weight (BW) on day 40, daily weight gain (DWG), daily feed intake (DFI), and feed conversion ratio (FCR). Daily feed intake was calculated as the difference between feed supply and feed residues, which were weighed at the beginning and end of the experimental period, divided by the number of days of feed supply. Birds were weighed at the beginning and end of the experimental period, divided by the number of days of the experimental period to determine daily weight gain. Feed conversion ratio was calculated by dividing accumulated feed intake by weight gain during the period, adjusted by feed residue weight and dead bird weight.

Mortality and flock health status (birds with abnormal development were removed) were daily monitored and recorded.

At the end of the experimental period, when birds were 40 days old, two birds representing $\pm 10 \%$ average body weight of each experimental unit were selected, totaling 100 birds or 10 birds per treatment. These birds were identified, submitted to 6-h feed fasting to empty the gastrointestinal tract, individually weighed, and slaughtered according to humane slaughter methods. After bleeding, plucking, manual evisceration, and head removal, carcasses were weighed. Carcass yield (CY) was calculated as empty carcass weight relative to live weight after fasting. Carcasses were then cut up by a single trained person and parts were individually weighed. Breast yield (BY), leg (thighs + drumstick) yield (LY), wing yield (WY), and abdominal fat (AF) were calculated relative to empty carcass weight.

Data were analyzed using the Statistical Analysis System package (SAS Institute Inc., 2008) after testing the residue normality by the test of ShapiroWilk (PROC UNIVARIATE). Performance and carcass yield data were submitted to analysis of variance
Evaluation of Different Digestible Lysine Levels for Male Broilers During the Period of 18 to 40 Days of Age

using the MIXED procedure, which separated effects of treatment as causes of variation. The effect of treatment (dietary lysine levels) was evaluated using polynomial regression, separating the effects as linear, quadratic, cubic, and deviation of the cubic effect.

\section{RESULTS AND DISCUSSION}

During the period of 18-40 days of age, there was a quadratic effect $(p<0.05)$ of digestible lysine levels on average body weight at 40 days of age (BW) and daily weight gain (DWG), and a cubic effect on feed conversion ratio (FCR), as shown in Table 3, and Figures 1,2 , and 3 , respectively.

Figures 1 - Average body weight of male broilers at 40 days of age.

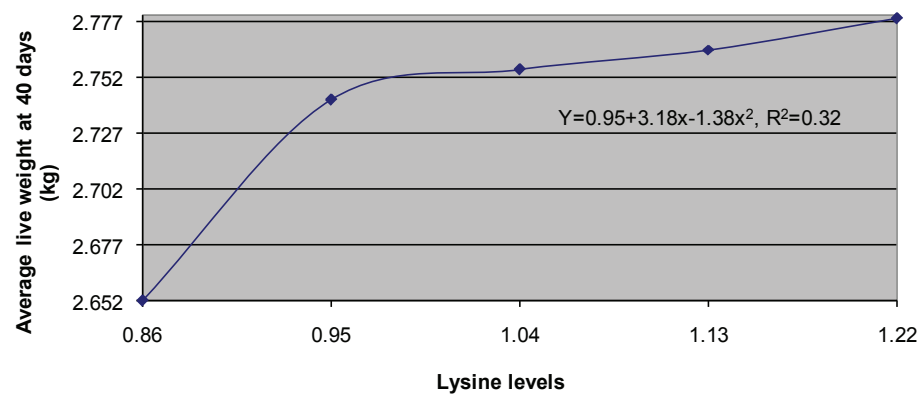

Figures $\mathbf{2}$ - Daily weight gain of male broilers between 18 and 40 days of age.

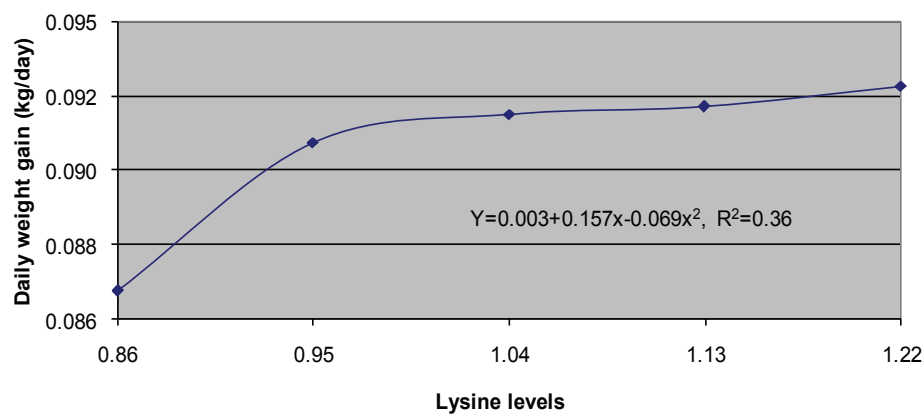

Table 3 - Performance of male broilers during the period of 18 to 40 days of age.

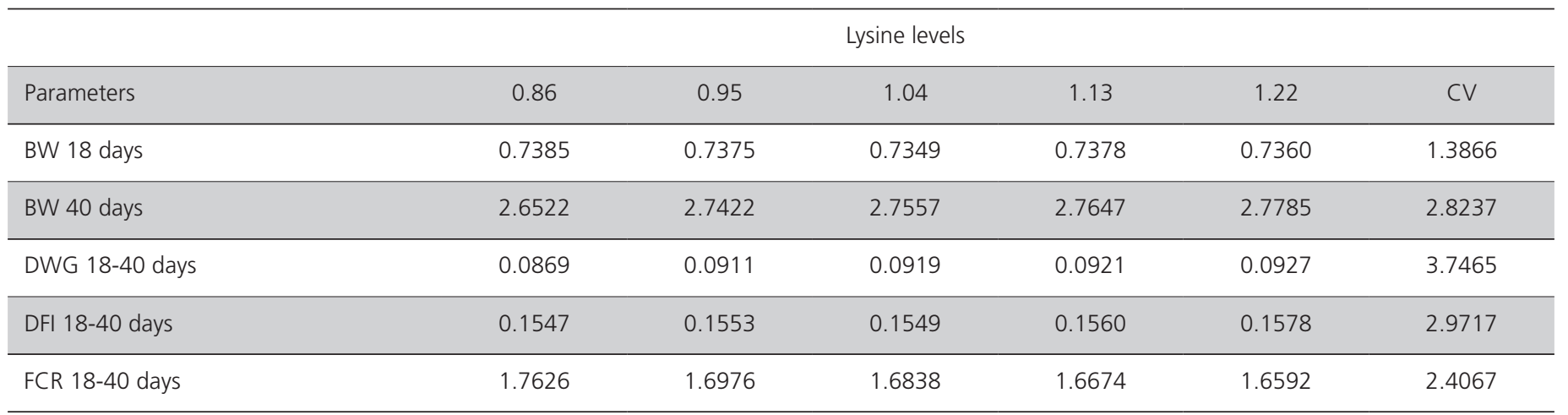


Carlos TCF, Marino CT, Silva NVP da, Barbosa LCGS, Reis RN, Muramatsu K, Araújo CS da S, Araújo LF

Figures 3 - Feed conversion ratio of male broilers between 18 and 40 days of age.

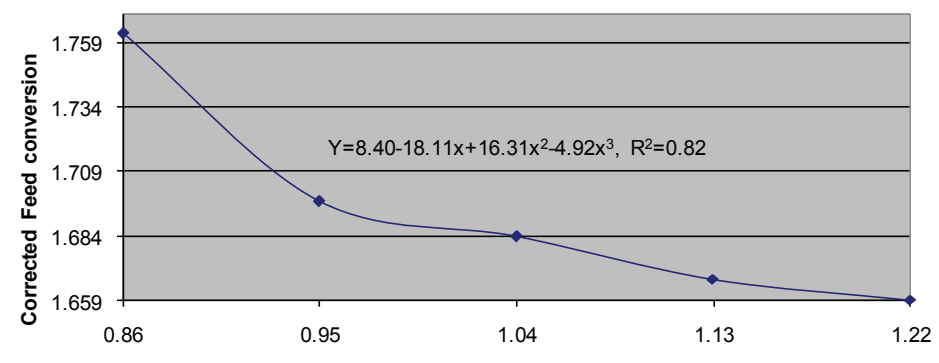

Lysine levels

The heaviest body weight at 40 days of age, highest daily weight gain, and best feed conversion ratio were obtained in broilers fed $1.22 \%$ digestible lysine. Rostagno et al. (2011) recommended 1.131\% digestible lysine and $19.8 \%$ crude protein dietary levels for high-performance male broilers during the period of 22 to 33 days of age, and $1.060 \%$ digestible lysine and $18.4 \%$ crude protein for the period of 34 to 42 days of age.

There was no influence of lysine levels of daily feed intake (DFI) carcass yield (CY), leg yield (LY), or wing yields (WY). Viola et al. (2009), evaluating different digestible lysine levels for male Cobb broilers, also did not find any effects on feed intake, and demonstrated that there was no compensatory intake of broilers fed limiting digestible lysine levels, consistent with the findings of Labadan et al. (2001) and Corzo et al. (2002).

There was a quadratic effect on breast yield (BY) and a cubic effect on abdominal fat (AF), as shown in Table 4 and Figures 4 and 5, respectively.

Figures 4 - Breast yield of male broilers fed different digestible lysine levels between 18 and 40 days of age.

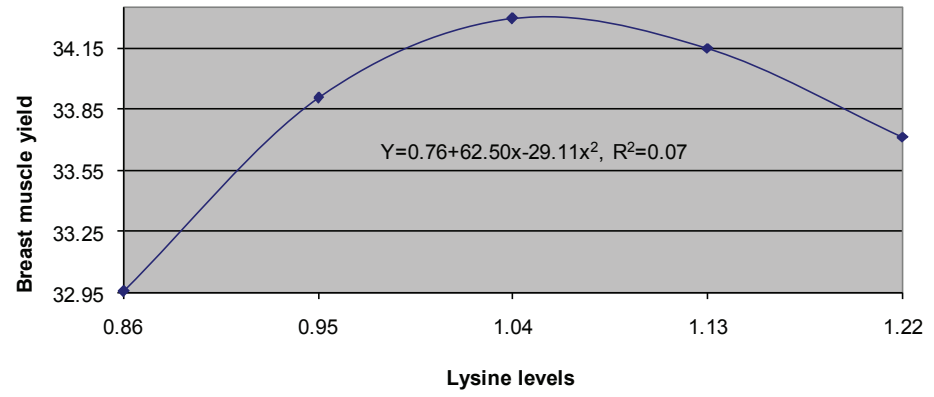

Evaluation of Different Digestible Lysine Levels for Male Broilers During the Period of 18 to 40 Days of Age

Figures 5 - Abdominal fat yield of male broilers fed different digestible lysine levels between 18 and 40 days of age.

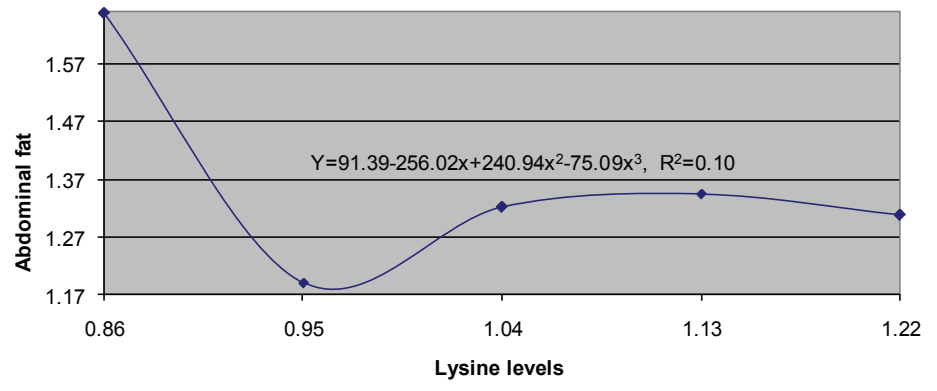

The greatest breast yield was obtained when 1.04\% digestible lysine was fed, and the lowest abdominal fat content with $0.95 \%$ digestible lysine. This greater breast yield is due to the fact that lysine is used for body protein accretion, and in the specific case of the breast muscle, lysine is better utilized due to its type of muscle fibers (Leclercq, 1998).

The supplementation of the diet with amino acids improves carcass quality (Fancher \& Jensen, 1989), particularly breast yield. However, amino acids in excess of the requirements for protein synthesis need to be broken down. The resulting nitrogen is excreted in the urine and the carbon skeleton can be used for glucose synthesis, converted in fat or in $\mathrm{CO}_{2}$ and $\mathrm{H}_{2} \mathrm{O}$ (Scott et al, 1982), thereby increasing energy metabolism.

Abdominal fat percentage is a good estimate of carcass fat percentage due to the high correlation (0.75) between them. Abdominal fat can be reduced due to lower availability of excessive energy for storage as a result of energy utilization for meat deposition in the carcass.

According to Viola et al. (2009), several authors obtained higher weight gain and better feed conversion ratio as digestible lysine supplementation levels increased in the diet of 21- to 40-d-old broilers (Emmert et al., 1999, Mack et al., 1999). Mack et al. (1999) estimated considerably higher digestible lysine requirements for feed conversion ratio $(1.16 \%)$ and weight gain compared with that for breast weight gain (0.87\%). Corzo et al. (2002) observed that feed conversion ratio linearly improved when dietary lysine

Table 4 - Carcass yield of 40-d-old male broilers fed different digestible lysine levels between 18 and 40 days of age.

\begin{tabular}{|c|c|c|c|c|c|c|}
\hline & & & Lysine level & & & \\
\hline Parameters & 0.86 & 0.95 & 1.04 & 1.13 & 1.22 & CV \\
\hline CY & 80.2243 & 80.6635 & 80.7264 & 80.3745 & 80.4786 & 1.7452 \\
\hline BY & 32.9593 & 33.9054 & 34.2981 & 34.1526 & 33.7163 & 5.3660 \\
\hline$L Y$ & 27.3235 & 26.6030 & 26.7192 & 26.7677 & 26.8451 & 4.1392 \\
\hline WY & 10.4456 & 10.2653 & 10.1232 & 10.1764 & 10.7722 & 5.9905 \\
\hline$A F$ & 1.6574 & 1.1909 & 1.3211 & 1.3448 & 1.3077 & 34.3958 \\
\hline
\end{tabular}


Carlos TCF, Marino CT, Silva NVP da,

Barbosa LCGS, Reis RN, Muramatsu K,

Araújo CS da S, Araújo LF

levels increased from 0.75 to $1.15 \%$ even after 42 days of age.

Leclercq (1998) and Mack et al. (1999) noted that the optimal digestible lysine level is different for each evaluated parameter and should be determined in the formulation according to the parameter desired at field level. According to Leclercq (1998), lysine requirement for maximum weight gain is lower than that for breast meat yield, which is lower than for feed conversion ratio, whereas for reducing abdominal fat deposition is the highest. This relation was not observed in the present study, as digestible lysine levels for weight gain and feed conversion ratio were equal and higher than for breast yield, which in turn was higher than for abdominal fat deposition.

\section{CONCLUSIONS}

Under the conditions described in the present study, digestible lysine requirements for male broilers during the period of 18 to 40 days of age was $1.22 \%$ for performance and $1.04 \%$ for carcass yield.

\section{REFERENCES}

Almeida ICL, Mendes AA, Garcia RG, Takita TS, Moreira J, Garcia EA. Efeito do nível de lisina da dieta e do sexo sobre o desempenho e rendimento de carcaça de frangos de corte. Revista Brasileira de Ciência Avícola; $4(1): 1-8$.

Barbosa MJB, Junqueira OM, Andreotti MO, Cancherini LC. Exigências de lisina e metionina+cistina digestíveis em dietas para frangos de corte na fase de crescimento. Acta Scientiarum 2001;23(4):909-915.

Buteri CB, Tavernari FC, Rostagno HS, Albino LFT. Exigência de lisina, planos nutricionais e modelos matemáticos na determinação de exigências de frangos de corte. Acta Veterinaria Brasilica, 2009; 3(2):48-61.

COBB. Cobb 500 Suplemento de Crescimento e Nutrição para Frangos de Corte. São Paulo: Cobb-Vantress Brasil, 2008. 8p.

Conhalato GS. Exigência de lisina digestível para frangos de corte machos. 1998. 79 f. Dissertação (Mestrado em Zootecnia) Universidade Federal de Viçosa, Viçosa, 1998.
Evaluation of Different Digestible Lysine Levels for Male Broilers During the Period of 18 to 40 Days of Age

Corzo A, Moran Jr. ET, Hoehler D. Lysine need of heavy broiler males applying the ideal protein concept. Poultry Science 2002;81:1863-1868.

Costa FGP, Amarante Junior VS, Nascimento GAJ, Brandão PA, Barros LR, Silva JHV. et al. Níveis de lisina para frangos de corte nos períodos de 22 a 42 e de 43 a 49 dias de idade. Ciência e Agrotecnologia 2006;30(4):759-766.

Fancher B, Jensen LS. Influence on performance of three to six-week old broilers of varying dietary protein contents with supplementation of essencial amino acid requirements. Poultry Science 1989;68:113-123.

Goulart CC, Costa FGP, Lima Neto RC, Souza JG, Silva JHV, Givisiez PEN. Exigência de lisina digestível para frangos de corte machos de 1 a 42 dias de idade. Revista Brasileira de Zootecnia 2008(37)5:876-882.

Labadan MC, Hsu KN, Austic RE. Lysine and arginine requirements of broiler chickens at two- to three-week intervals to eight weeks of age. Poultry Science 2001. 80:599-606.

Lana SRV, Oliveira RFM, Donzele JL, Albino LFT, Gomes PC, Vaz RGMV. et al. Níveis de lisina digestível em rações para frangos de corte de 22 a 42 dias de idade, mantidos em ambiente de termoneutralidade. Revista Brasileira de Zootecnia, 2005; 34(5):1624-1632.

Leclercq B. Specific effects of lysine on broiler production: Comparison with threonine and valine. Poultry Science 1998;77:118-123.

Mack S, Bercovici D, De Groote G, Leclercq B, Lippens M, Pack M. et al. Ideal amino acid profile and dietary lysine specification for broiler chickens of 20 to 40 days of age. British Poultry Science 1999;40:257-265.

Rostagno HS, Albino LFT, Donzele JL, Gomes PC, Oliveira RF, Lopes DC, et al. Tabelas Brasileiras para Aves e Suínos: Composição de alimentos e exigências nutricionais. $3^{a}$ ed. Viçosa: UFV, DZO; 2011. 252p.

SAS Institute. SAS User's Guide: Statistics. Version 9.2 ed. [CD-ROM]. Cary; 2008

Scott ML, Nesheim MC, Young RJ. Nutrition of the chicken. $3^{\text {rded. Ithaca: }}$ [s.n.]; 1982. 562 p.

Trindade Neto MA, Takeara P, Toledo AL, Kobashigawa E, Albuquerque R, Araújo LF. Níveis de lisina digestível para frangos de corte machos no período de 37 a 49 dias de idade. Revista Brasileira de Zootecnia 2009;38(3):508-514.

Viola TH, Kessler AM, Ribeiro AML, Viola ES, Trevizan L, Gonçalves TA. Desempenho e peso de frações corporais, na suplementação crescente de lisina, dos 19 aos 40 dias de idade em frangos de corte. Ciência Rural 2009;39(2):515-521. 